\title{
ЗАСАДИ ФОРМУВАННЯ РИНКУ ПЕРСОНАЛЬНИХ ДАНИХ ГРОМАДЯН: БЕЗПЕКОВИЙ ЗРІЗ
}

\author{
Елена Шандривска \\ ОСНОВЫ ФОРМИРОВАНИЯ РЫНКА ПЕРСОНАЛЬНЫХ ДАННЫХ \\ ГРАЖДАН: НАПРАВЛЕНИЕ ПО ОБЕСПЕЧЕНИЮ БЕЗОПАСНОСТИ
}

\author{
Olena Shandrivska \\ BASES OF FORMING PERSONAL DATA MARKET \\ FOR CITIZENS: SECURITY DIRECTION
}

\begin{abstract}
Проаналізовано світовий досвід передумов формування ринку персональних даних споживачів, зокрема з погляду забезпечення доступу зачікавлених груп стейкхолдерів до нього. Проведено кількісний та якісний аналіз показників, щуо ідентифікують кон'юнктуру ринку персональних даних в Україні, компонентний склад якої включає економічно активне населення, домашні абоненти мережі Інтернет, темпи проникнення Інтернету, наявний дохід у розрахунку на одну особу, обліковані кіберзлочини; сформульовано засади упорядкування суспільних інформачійних відносин у частині захисту персональних даних на основі формування єдиної системи захисту персональних даних та сформовано напрями мінімізачії ризиків витоку персональних даних споживачів
\end{abstract}

Ключові слова: великі дані; проникнення Інтернету; ичифровий розвиток; безпека персональних даних; обліковані кіберзлочини; ринок персональних даних; доступ до ринку персональних даних

Рис.: 1. Табл.: 1. Бібл.: 14.

Проанализирован мировой опьт предпосылок формирования рынка персональных данных потребителей, в частности с точки зрения обеспечения доступа заинтересованных к нему групп стейкхолдеров. Наведена кониептуальная схема формирования рынка персональных данных граждан. Проведен количественный и качественный анализ показателей, идентифицирующих конъюнктуру рынка персональных данных, к которым в работе отнесень показатели: экономически активное население, домашние абоненты сети Интернет, темпь проникновения Интернета, имеющийся доход в расчете на одного человека, учтенные киберпреступления); сформулированы основы упорядочения общественных информациионных отночений в части зашуиты персональных данных на основании формирования единой системы защиты персональных данных, сформированы направления минимизации рисков утечки персональных данных потребителей.

Ключевые слова: больиие данные; проникновение Интернета; ичифровое развитие; безопасность персональных данных; учтенные киберпреступления; рынок персональных данных; доступ к рынку персональных данных

Рис.: 1. Табл.: 1. Библ.: 14.

The world experience of the prerequisites for the formation of a consumer personal data market has been analyzed, in particular from the point of view of providing access to stakeholder groups interested in it. A conceptual scheme of the formation of a market for personal data has been introduced. A quantitative and qualitative analysis of indicators that identify the conditions of the personal data market has been carried out. The following indicators has been included in the work: economically active population, Internet home subscribers, Internet connectivity rates, available income per capita, and recorded cybercrimes. The basics of streamlining public information relations in terms of personal data protection based on the formation of a unified system of personal data protection has been formulated, methods for minimizing the risks of leakage of consumers personal data has been developed.

Keywords: big data; Internet penetration; digital development; personal data security; counted cybercrime; personal data market; access to the personal data market.

Fig.: 1. Table: 1. References: 14.

JEL Classification: M31

Постановка проблеми. Тренди глобалізації та інформатизації українського суспільства в умовах поширення четвертої промислової революції глибоко проникають та трансформують природу національної та інформаційної безпеки держави, формують автентичну, притаманну для України, модель інформаційної безпеки та впливають на ринкові процеси в інформаційній галузі. Інформаційна складова гібридної агресії, впроваджувана Російською Федерацією проти України, яка активно супроводжується масштабними кібератаками на об’єкти критичної інфраструктури, системи управління технологічними процесами підприємств, державні фінансові організації тощо, сприяє розбудові власної моделі забезпечення інформаційної безпеки, заснованої на інтересах, цінностях та надбаннях українського суспільства в інформаційній сфері, з пріоритиза-

(с) Шандрівська О. Є., 2019 
цією зусиль на інформаційних технологіях, що супроводжують процеси запобігання війн, збройних конфліктів, формування інформаційного суспільства та безпекової складової інформаційного ринку України.

У зв'язку з цим можна стверджувати, що в Україні виникла потреба в інституціоналізації процесу формування ринку персональних даних, особливо в частині регламентування та врегулювання суспільних інформаційних відносин, пов'язаних із безпекою персональних даних та інформаційним самовизначенням.

Аналіз останніх досліджень і публікацій. Прогрес у прикладних технологіях, швидкості інтернет-з'єднання і законодавчих заходів, таких як GDPR, перетворив тенденції продажу доступу до персональних даних із розряду концепцій у реальність та сприяв становленню ринку персональних даних. Так, поява Служби менеджера особистої інформації, PIMS, у розвинутих країнах засвідчила одну зі складових формалізації ринку персональних даних (класифікація персональних даних наведена у [12]).

Наприклад, VETRI додаток, який складається з бази даних і торгового майданчика, дозволяє зберігати й управляти споживачами своїми персональними даними, а торговельний майданчик - анонімно продавати доступ до частини цих даних дослідникам, підприємствам, маркетологам чи іншим групам стейкхолдерів. Зі зростанням кількості наданої персональної інформації споживачі прагнуть посилювати контроль їх обігу в інформаційному просторі, а отже, у наданні доступу до персональних даних, зокрема платного. Згідно $з$ даними агентства SAS і аналітиків Future Foundation, до $69 \%$ мілленіалів (людей віком 16-34 роки) готові надати платний доступ до своїх персональних даних. Із них 67 \% надали б персональні дані в секторі охорони здоров'я, $57 \%$ - у фінансовому секторі, 50 \% - у державному секторі, в той час як 45 \% готові до надання персональних даних постачальникам енергії, 32 \% - торговцям і 28 \% - засобами масової інформації [14].

У світовій практиці виділяють ринок персональних даних, який являє собою сховище персональних даних із контрольованим доступом з боку споживачів до їх персональних даних зацікавленим групам стейкхолдерів, який вирізняється своєю незрілістю, та ринок хмарних сховищ (The market for personal clouds), який більш зрілий. Наприклад, у переліку великих даних зі хмарних сховищ $\epsilon$ вебсторінки, звички перегляду, сенсорні сигнали, дані щодо місцезнаходження смартфонів, геномна інформація тощо, яка ідентифікується як новий вид активів. Серед площадок, які представляють ринок хмарних сховищ, можна виділити Cozy, Freedom Box, NextCloud та My Cloud, натомість децентралізованими вебдодатками ринку персональних даних $є$ SoLiD, MyDex, Digi.me, Hub of all [13].

Слід відзначити гостру актуальність досліджень проблеми персональних даних: ще у 2011-2012 рр. на Всесвітньому економічному форумі персональні дані споживачів було названо новим класом активів і складною економічною системою організацій, що працюють у сфері збирання та обробки особистої інформації громадян.

У вітчизняній практиці положення щодо структуризації персональних даних, чи їх захисту в межах конституційного, інформаційного та міжнародного права становили науковий інтерес таких вчених, як Т. Обуховська, О. Кулініч, В. Ліпкан, О. Логінов, Ю. Максименко, А. Марущак, П. Матвієнко, Н. Нижник, А. Новицький, А. Пазюк, О. Рябченко, І. Сопілко, В. Цимбалюк, М. Швець, О. Фролова та інші. Серед закорлонних науковців ці питання розглядали Ф. Агре, К. Беннетт, Д. Беркін, Л. Брейдейс, С. Воррен, С. Дейвіс, В. Іванський, та ін.

Виділення недосліджених частин загальної проблеми. Проте питання становлення вітчизняного ринку персональних даних у частині маркетингових аспектів забезпечення безпеки персональних даних та аналізу взаємовпливів різних груп стейкхолдерів на ньому досліджено недостатньо, що актуалізує дослідження окресленої проблеми. 
ГАЛУЗЕВИЙ АСПЕКТ РОЗВИТКУ НАЦІОНАЛЬНОГО ГОСПОДАРСТВА

Мета статті. Розкрити засади формування вітчизняного ринку персональних даних у частині ідентифікації політики безпеки персональних даних в Україні, здійснити аналіз показників, що ідентифікують кон'юнктуру ринку персональних даних; сформувати концептуальну схему функціонування ринку персональних даних громадян; розкрити засади упорядкування суспільних інформаційних відносин у частині захисту персональних даних громадян.

Виклад основного матеріалу. 3 впровадженням в Україні цифрових технологій, де серед іншого закладені заходи щодо розвитку кібербезпеки та хмарних технологій збереження даних, інформаційно-телекомунікаційних систем у всі сфери життєдіяльності, актуалізації бізнес-орієнтованого підходу до процесів діджиталізації [2, с. 21-32], за яких інформація набула функцій товару та розглядається як потужний ресурс розвитку та підвищення конкурентоспроможності, виникла проблема формування раціональної поведінки споживачів як носіїв персональних даних та захисту даних на ринку персональних даних громадян, концептуальна схема якого наведена на рис. 1 .

Щорічна статистика [7] вказує на появу не тільки недостатнього рівня відстежуваності витоків та наявності часового лагу щодо фактів реєстрування витоків даних відносно часу їх настання, а й формування соціальних, економічних та політичних ризиків, пов'язаних 3 інтерпретацією персональних даних та прав власності на них, засвідчує виникнення потреби в контролі та регулюванні доступу та/або володінні базами персональних даних споживачів, та, відповідно, згідно із законами попиту та пропозиції, формування політики регулювання ринків персональних даних громадян, зокрема в частині розробки засад трактування поняття «персональні дані» та їх належності до носіїв цих даних, оскільки залишається невирішеною дилема трактування персональних даних як товару з притаманними для нього функціями та атрибутами (цінність, ексклюзивність, конфіденційність, невідчужність та ін.) у ринковому просторі та їх інтерпретації як немайнової власності громадян; організаційно-економічних та технікотехнологічних засад захисту інформаційних активів та безпекових аспектів захисту персональних даних.

Аналіз витоків персональних даних засвідчив, що в умовах конвергенції традиційної та електронної форм комерції, які здійснюються завдяки розширенню доступу до мережі Інтернет, активному розвиткові соцмереж, поширенню хмарних технологій та технологій Великих Даних тощо у сучасному ринковому просторі їх джерелами виступають не тільки такі системи інформаційної та економічної взаємодії, як бізнес до бізнесу (b2b), бізнес до споживача (b2c), споживач до споживача (c2c), бізнес до уряду $($ в2g), уряд до споживача (g2c), а й системи економічної самоорганізації учасників горизонтальних мереж (p2p), спільного споживання (однорангового обміну) на противагу ринковому ціноутворенню та директивному управлінню та інші.

Серед моделей пропозиції для споживачів, які активно застосовуються на ринку персональних даних розвинутих країн, слід виділити: моделі за рівнем доступу та розвитком посередництва щодо персональних даних; моделі з оплатою за контроль конфіденційності, коли серед пропозицій виділяють безкоштовний продукт, базовий платний продукт та преміумпродукт із вищою конфіденційністю та контролем даних; та модель, що грунтується на рівнях активності споживачів як учасників ринкових відносин під назвою «економіка персональних даних» [10]. Очікується, що надалі зазначені моделі економічних відносин на ринку персональних даних активно поширюватимуться на теренах України.

Відповідно виникає необхідність в ідентифікації рівня/індексу довіри та структуризації масової інформації в частині змістовного наповнення понять «достовірна, збалансована інформація»/«дезінформація», «витоки інформації», «безпека персональних даних» тощо, які сприятимуть ідентифікації економічних засад функціонування вітчизняного ринку персональних даних та його безпекових складових. 


\begin{tabular}{|c|c|c|c|c|c|c|c|c|c|c|}
\hline \multicolumn{11}{|c|}{ Структура інформаційного середовища } \\
\hline \multicolumn{2}{|l|}{5} & \multicolumn{2}{|c|}{$\underline{t}$} & \multicolumn{3}{|c|}{$\mathbf{7}$} & \multicolumn{2}{|r|}{$\dot{t}$} & \multicolumn{2}{|r|}{$\nabla$} \\
\hline \multicolumn{2}{|c|}{$\begin{array}{c}\text { Суб’єкти } \\
\text { інформаційного } \\
\text { ринку }\end{array}$} & \multicolumn{2}{|c|}{$\begin{array}{l}\text { Інформаційна } \\
\text { інфраструк- } \\
\text { тура }\end{array}$} & \multicolumn{4}{|c|}{$\begin{array}{c}\text { Інформаційно- } \\
\text { комунікативний простір, } \\
\text { утворений потоками } \\
\text { інформації }\end{array}$} & $\begin{array}{l}\text { нформаційні } \\
\text { ресурси } \\
\text { (бази даних) }\end{array}$ & \multicolumn{2}{|c|}{$\begin{array}{c}\text { Ринкові відносини у } \\
\text { сфері управління } \\
\text { інформаційними } \\
\text { потоками }\end{array}$} \\
\hline \multicolumn{11}{|c|}{$\sqrt{\Gamma}$} \\
\hline \multicolumn{11}{|c|}{ Суб’єкти відносин, пов’язані функціями управління персональними даними } \\
\hline \multicolumn{2}{|l|}{$\nabla$} & \multicolumn{2}{|r|}{$\nabla$} & \multicolumn{3}{|c|}{ 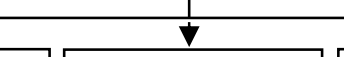 } & \multicolumn{2}{|r|}{$\dot{\nabla}$} & \multicolumn{2}{|r|}{$\nabla$} \\
\hline $\begin{array}{c}\text { Особа - } \\
\text { носій } \\
\text { персональ- } \\
\text { них даних }\end{array}$ & \multicolumn{4}{|c|}{$\begin{array}{c}\text { Володілець/розпорядник } \\
\text { даних: працедавці, } \\
\text { банки, комунальні } \\
\text { служби... }\end{array}$} & \multicolumn{2}{|c|}{$\begin{array}{l}\text { Треті особи, } \\
\text { яким передано } \\
\text { дані для } \\
\text { обробки }\end{array}$} & \multicolumn{2}{|c|}{$\begin{array}{c}\text { Уповноважений } \\
\text { державний орган та } \\
\text { інші з питань } \\
\text { захисту даних }\end{array}$} & \multicolumn{2}{|c|}{$\begin{array}{l}\text { Інші особи, що не- } \\
\text { санкціоновано } \\
\text { отримали доступ до } \\
\text { персональних даних }\end{array}$} \\
\hline \multicolumn{11}{|c|}{$\sqrt{2}$} \\
\hline \multicolumn{11}{|c|}{ Джерела витоку персональних даних в ринковому середовищі, зокрема й інтернет-просторі } \\
\hline$\nabla$ & & $\bar{v}$ & & & 7 & & & $\nabla$ & $\nabla$ & $\boldsymbol{\nabla}$ \\
\hline $\begin{array}{c}\text { с2с - спо- } \\
\text { живач до } \\
\text { споживача } \\
\text { (інтернет- } \\
\text { магазини } \\
\text { електронні } \\
\text { аукціони) }\end{array}$ & $\begin{array}{l}\text { c2g } \\
\text { мадс } \\
\text { до д } \\
\text { них }\end{array}$ & $\begin{array}{l}\text { - гро- } \\
\text { ськість } \\
\text { ержав- } \\
\text { служб }\end{array}$ & $\begin{array}{r}\mathrm{b} 2 \mathrm{e} \\
\text { проце } \\
\text { вець } \\
\text { співрс } \\
\text { тник }\end{array}$ & & $\begin{array}{c}\text { b2b - } \\
\text { бізнес до } \\
\text { бізнесу } \\
\text { (вебвітри- } \\
\text { ни, торго- } \\
\text { вельні } \\
\text { майданчи- } \\
\text { ки, аук- } \\
\text { ціони) }\end{array}$ & $\begin{array}{c}\text { p2p - } \\
\text { номі } \\
\text { само } \\
\text { ганіза } \\
\text { учасн } \\
\text { гориз } \\
\text { тальн } \\
\text { мере }\end{array}$ & $\begin{array}{l}\text { ко- } \\
\text { на } \\
\text { p- } \\
\text { ція } \\
\text { ків } \\
\text { H- } \\
\text { их } \\
\text { к }\end{array}$ & $\begin{array}{c}\text { Економіка } \\
\text { спільного } \\
\text { споживання } \\
\text { (одноранго- } \\
\text { вий обмін) }\end{array}$ & $\begin{array}{c}\text { в2g - } \\
\text { бізнес до } \\
\text { уряду } \\
\text { (торго- } \\
\text { вельні } \\
\text { майдан- } \\
\text { чики) }\end{array}$ & $\begin{array}{c}\mathrm{b} 2 \mathrm{c}- \\
\text { бізнес до } \\
\text { спожива- } \\
\text { ча; } \\
\text { с2b - } \\
\text { (сайти- } \\
\text { каталоги) }\end{array}$ \\
\hline
\end{tabular}

Потенційні моделі- пропозиції (1; 2) та попиту (3) на ринку персональних даних

\begin{tabular}{|c|c|c|c|c|c|}
\hline $\begin{array}{l}\text { 1. Моделі за ознакою } \\
\text { доступу та посередницт- } \\
\text { ва щодо персональних } \\
\text { даних }\end{array}$ & $\begin{array}{l}\text { 2. Моделі з оп } \\
\text { позиції: безкоц } \\
\text { та преміум-пр } \\
\text { ролем даних) }\end{array}$ & $\begin{array}{l}\text { атою } \\
\text { товни } \\
\text { дукт }\end{array}$ & $\begin{array}{l}\text { за контроль конфі, } \\
\text { й продукт, базовий } \\
\text { вищою конфіденг }\end{array}$ & $\begin{array}{l}\text { пенційності (про- } \\
\text { платний продукт } \\
\text { (ійністю та конт- }\end{array}$ & $\begin{array}{l}\text { 3. Модель еконо- } \\
\text { міки персональ- } \\
\text { них даних }\end{array}$ \\
\hline \multicolumn{3}{|c|}{$\begin{array}{l}\text { 1.1. Модель «дані як оплата»- отримання до- } \\
\text { ходу від продажів персональних даних чи рек- } \\
\text { лами (базується на збиранні та монетизації пер- } \\
\text { сональних даних) }\end{array}$} & \multicolumn{3}{|c|}{$\begin{array}{l}\text { 1.2. Модель «безкоштовно та преміум» - безкоштовна } \\
\text { пропозиція базових функцій/ платформ, } 3 \text { додатковою } \\
\text { оплатою за доступ до розширених функцій/ преміум } \\
\text { версії платформи }\end{array}$} \\
\hline \multicolumn{2}{|c|}{$\begin{array}{l}\text { 2.1. Конфіденційність як розкіш (широкі } \\
\text { можливостей рівнів конфіденційності та } \\
\text { захисту даних за преміум-цінами) }\end{array}$} & \multicolumn{2}{|c|}{$\begin{array}{l}\text { 2.2. Модель оплати } \\
\text { конфіденційність } \\
\text { основі підписки }\end{array}$} & \multicolumn{2}{|c|}{$\begin{array}{l}\text { 2.3. Модель оплати за контроль кон- } \\
\text { фіденційності з пропозицією програ- } \\
\text { ми знижок за відмову від конфіден- } \\
\text { ційності }\end{array}$} \\
\hline \multicolumn{4}{|c|}{$\begin{array}{l}\text { 3.1. Модель аналізу даних (управління власними персональними } \\
\text { даними (компіляція, агрегування, отримання аналітики) через пла- } \\
\text { тформи; надання користувачам доступу до ринку для монетизації } \\
\text { даних) }\end{array}$} & \multicolumn{2}{|c|}{$\begin{array}{l}\text { 3.2. Модель передачі даних/ надання } \\
\text { доступу до них володільцям/ третім } \\
\text { сторонам через торгові майданчики } \\
\text { PDE }\end{array}$} \\
\hline
\end{tabular}

Рис. 1. Концептуальна схема становлення вітчизняного ринку персональних даних

Джерело: власна розробка; світовий досвід моделей попиту - пропозиції розглянуто в [10]. 
ГАЛУЗЕВИЙ АСПЕКТ РОЗВИТКУ НАЦІОНАЛЬНОГО ГОСПОДАРСТВА

3 огляду на зазначене, до показників, що ідентифікують динаміку та проблему розвитку кон'юнктури ринку персональних даних в Україні, нами віднесено економічно активне населення, тис. осіб; домашні абоненти мережі Інтернет, тис.; наявний дохід у розрахунку на одну особу, грн; а в контексті розгляду безпекових аспектів - обліковані кіберзлочини, од., аналіз динаміки яких наведено в табл. 1.

Таблиця 1

Показники ідентифікації безпеки персональних даних громадян в Україні

\begin{tabular}{|c|c|c|c|c|c|c|}
\hline Рік & $\begin{array}{c}\text { Економічно } \\
\text { активне на- } \\
\text { селення, } \\
\text { тис. осіб } \\
\end{array}$ & $\begin{array}{l}\text { Домашні або- } \\
\text { ненти мережі } \\
\text { Інтернет, тис. }\end{array}$ & $\begin{array}{c}\text { Довідково: } \\
\text { темпи прони- } \\
\text { кнення } \\
\text { Інтернету, \% }\end{array}$ & $\begin{array}{c}\text { Наявний дохід } \\
\text { у розрахунку } \\
\text { на одну особу, } \\
\text { грн } \\
\end{array}$ & $\begin{array}{c}\text { Довідково: } \\
\text { кількість } \\
\text { населення, } \\
\text { тис. } \\
\end{array}$ & $\begin{array}{c}\text { Обліковані } \\
\text { кіберзлочини, } \\
\text { од. }\end{array}$ \\
\hline 2005 & 20481,7 & 266,775 & 15 & 6332 & 46929,5 & 39 \\
\hline 2010 & 20220,7 & 3661,2 & 33 & 18485,6 & 45778,5 & 190 \\
\hline 2015 & 17396,0 & 5625,1 & 58 & 31803,1 & 42760,5 & 598 \\
\hline 2016 & 17303,6 & 15493,1 & 63 & 37079,9 & 42584,5 & 865 \\
\hline 2017 & 17193,2 & 20619,0 & 64 & 47269,7 & 42386,4 & 2573 \\
\hline 2018 & 17296,2 & 23354,2 & 63 & 58442 & 42153,2 & 2688 \\
\hline 2019 & 17323,7 & 25683,8 & 71 & 67208,3 & 41902,4 & 4263 \\
\hline $\begin{array}{l}2019 / \\
2005\end{array}$ & 0,85 & 96,28 & 4,73 & 10,61 & 0,89 & 109,31 \\
\hline
\end{tabular}

Джерело [3-5; 8].

Кількісний аналіз показників, що ідентифікують кон'юнктуру сегменту персональних даних (табл. 1) в Україні засвідчив:

- об'єктивну тенденцію зниження темпів зростання економічно активного населення (0,85 у 2019 році відносно 2005 р.), пов'язану з виїздом трудових мігрантів до Польщі, Німеччини, Словаччини, Ізраїлю, Чехії, Угорщини та Литви, загальна кількість яких у 2018 році згідно з дослідженням Центру економічної стратегії становила 4 млн осіб [1] та зниженням кількості населення країни в цей період (темпи зростання - 0,89), через анексію Криму та воєнні дії в ОРДЛО;

- тенденцію до значного зростання кількості домашніх абонентів мережі Інтернет у 96,28 р. (2019 відносно 2005 р.), зважаючи на високі темпи проникнення Інтернету в Україні. У такий спосіб сприяючи розвиткові ринку електронної комерції та зростання його частки в загальному обсязі роздрібного продажу. Так, за даними BRDO, обсяг ринку е-commerce в Україні в 2017 р. перевищив 50 млрд \$, або 3,2 \% загального обсягу роздрібного продажу; щорічні темпи зростання цього сектору становлять 30 \%) [9];

- порівняно з темпами проникнення Інтернету в Україні, нижчих темпів зростання наявного доходу в розрахунку на одну особу (10,61 у 2019 відносно 2005 р.). Згідно 3 вітчизняною статистикою, Україна посідає передостаннє місце в Європі за ВВП на душу населення; останнє місце за рівнем проникнення мережі «Інтернет» і на 10-20 \% відстає від сусідніх країн за рівнем проникнення банківських карток [9]. Слушно зауважити, що за даними міжнародних інтернет-додатків, у 2019 р. Україна посіла друге місця після Німеччини (96\%) за рівнем проникнення Інтернет (93,4 \%), обійшовши Францію (92,3%), РФ (80,9 \%), Польщу (78,2 \%), США (77,2 \%), Грузію (68,1%) тощо [11];

- посилення уваги з боку компаній до ідентифікації профілю споживача з метою створення клієнто орієнтованих маркетингових стратегій, що передбачає активне використання персональних даних (тих, які ідентифікують особу та знеособлених). До прикладу, на замовлення Інтернет Асоціації України (ІнАУ) агенцією Factum Group Ukraine було проаналізовано соціально-демографічну структуру регулярних інтернет-користувачів, що $\epsilon$ обов'язковими показниками визначення цільової аудиторії [6, с. 33-44];

- суттєве зростання у країні облікованих кіберзлочинів (темпи зростання у 2019/2005 pp. - 109,31), які радше характеризують статистику розпізнавання злочинів, а не їх виявлення. 
ГАЛУЗЕВИЙ АСПЕКТ РОЗВИТКУ НАЦІОНАЛЬНОГО ГОСПОДАРСТВА

Якісний аналіз дозволив виявити специфіку формування безпекової складової ринку персональних даних, згідно до якої з'ясовано, що формування баз персональних даних в Україні, яке здійснюється інтенсивними темпами, засноване на перевищенні, а часто невідповідності обсягу та змісту інформації, яка збирається, відносно мети дослідження; безальтернативності в частині відмови від надання клієнтами персоніфікованої інформації, уразливості SMS-аутентифікації фінансових сервісів споживачів, не передбачає можливості контролю клієнтами подальших каналів передачі зібраної інформації, захисту від поширення неправдивої інформації, прав на знешкодження зібраної інформації та відновлення репутації, дуже часто відсутності механізмів ідентифікації витоків персональних даних та часового лагу між витоком персональних даних та фактом його ідентифікації, суттєвим перевищенням витрат на ідентифікацію витоку даних та знешкодження наслідків від їх здійснення відносно витрат на забезпечення інформаційної безпеки даних тощо.

Наприклад, на ринку фінансових послуг безпека персональних даних споживачів, яка грунтується на аутентифікації користувачів систем віддаленого обслуговування 3 прив'язкою до послуг мобільного зв'язку не відповідає сучасним вимогам забезпечення безпеки персональних даних. Зокрема, йдеться про відсутність зобов'язань використовувати клієнтами персоніфіковані послуги мобільного зв'язку, неможливість примусового блокування мобільного телефону для аутентифікації, відсутній обмін інформацією фінансових установ з операторами зв'язку для виявлення абонентів, які перебувають у групі ризику тощо. Політика фінансових установ у частині застосування практики використання номерів мобільного зв'язку для аутентифікації користувачів критично важливих додатків покладає ризики, пов'язані з безпекою персональних даних, на клієнтів - відсутністю укладання договорів із вигодонабувачами та компенсацію витрат тощо.

Необхідність дотримання безпеки персональних даних засвідчила появу потреби врегулювання поведінки суб'єктів відносин, пов'язаних із потоками персональних даних та розробки організаційно-економічного та правового механізму захисту персональних даних в Україні.

Упорядкування суспільних інформаційних відносин у частині захисту персональних даних в Україні потребує формування єдиної системи захисту персональних даних, заснованої на:

- прогресивних принципах захисту персональних даних (серед яких слід виділити забезпечення контролю процесів обробки персональних даних, оптимального співвідношення між правами доступу та захисту персональних даних, захищеність від несанкціонованого витоку та оброки персональних даних тощо) та має мати на меті підтримання оптимального балансу прав людини, суспільства та держави;

- організаційно-правовому механізмові захисту персональних даних, складовими якого мають стати впорядкування відповідальності суб'єктів ринку персональних даних, державний контроль завдяки ліцензуванню діяльності, пов'язаної із збиранням, передачею, обробкою, зберіганням та іншими маніпуляційними станами персональних даних, розробку стандартів щодо переліку маніпуляцій з персональними даними та сертифікування інформаційних систем з їх обробки;

- установленні реєстрів баз персональних даних, а також реєструванні володільців/ розпорядників даних, третіх осіб, яким передано персональні дані для подальшої обробки;

- створенні незалежного координаційного центру, цілепокладанням якого є здійснення державної політики у сфері нагляду за дотриманням вимог у сфері захисту персональних даних.

Висновки і пропозиції. Україна як держава з недостатнім рівнем захисту персональних даних громадян в умовах активного поширення інформаційно-комунікаційних технологій не спроможна забезпечити належний рівень інформаційної захищеності 
ГАЛУЗЕВИЙ АСПЕКТ РОЗВИТКУ НАЦІОНАЛЬНОГО ГОСПОДАРСТВА

споживачів від витоків конфіденційної інформації в ринковий інформаційний простір, що свідчить про наявність невирішених проблем на ринку персональних даних, який перебуває на стадії формування.

Запропонована до розгляду концептуальна схема становлення ринку персональних даних громадян, яка базується на окресленні структури інформаційного середовища, ідентифікації суб'єктів відносин, що пов'язані функціями управління персональними даними та джерел витоку персональних даних, зокрема в інтернет-просторі, а також представленні моделей попиту - пропозиції щодо управління персональними даними споживачів, частина з яких активно впроваджується на вітчизняному ринку персональних даних, засвідчила глибоку стурбованість з огляду на його слабку структурованість, значні ризики витоку персональних даних, низьку інформованість та недостатнє усвідомлення кінцевими споживачами потужного маркетингового впливу на свідомість та трансформацію запитів споживачів залежно від потреб конкретних груп стейкхолдерів, які здійснюють на них керований вплив із використання засобів Інтернету.

Оскільки у вітчизняній науковій літературі не достатньо приділено увагу засадам розвитку ринку персональних даних, то автором даного дослідження проаналізовано кон'юнктуру ринку персональних даних, на яку впливають: зниження темпів зростання економічно активного населення $(0,85$ у 2019 році відносно 2005 р.) через виїзд трудових мігрантів, зниження кількості населення країни у цей період (темпи зростання - 0,89) та анексію Криму; об' єктивну тенденцію до значного зростання кількості домашніх абонентів мережі Інтернет - у 96,28 р. (2019 відносно 2005 р.), зважаючи на високі темпи проникнення Інтернету в Україні; порівняно із темпами проникнення Інтернету в Україні, нижчих темпів зростання наявного доходу у розрахунку на одну особу $(10,61$ у 2019 відносно 2005 р.); зростання облікованих кіберзлочинів (темпи зростання у 2019/2005 pp. - 109,31), які радше характеризують статистику розпізнавання злочинів, а не їх ідентифікацію.

За умов низькоінституційованих засад формування ринку персональних даних громадян, обсяги збирання конфіденційної інформації не завжди відповідають меті дослідження і часто густо перевищують мінімально необхідний обсяг збирання інформації про особу, норма щодо якої має бути превентивно встановлена за замовчуванням.

Мінімізація ризиків витоку персональних даних споживачів можлива завдяки вдосконаленню нормативно-правового та організаційного-економічного забезпечення та приведення його у відповідність до положень GDPR, зокрема в контексті формування дієвої системи контролю суб'єктів інформаційного простору щодо управління інформаційними потоками на всіх стадіях збирання та обробки інформаційних ресурсів. На рівні громадськості необхідним є посилення культурно-просвітницької діяльності та підвищення поінформованості споживачів щодо правил комунікацій щодо дотримання безпеки персональних даних, зокрема й у соціальних мережах.

У роботі як пропозиція запропоновано розробити напрями упорядкування ринкових інформаційних відносин щодо захисту персональних даних громадян шляхом формування єдиної системи захисту персональних даних, заснованої на:

- прогресивних принципах захисту персональних даних: забезпечення контролю процесів обробки персональних даних, оптимального співвідношення між правами доступу та захисту персональних даних, захищеності від несанкціонованого витоку персональних даних;

- формуванні організаційно-економічного та правового механізму захисту персональних даних шляхом впорядкування відповідальності суб'єктів ринку персональних даних, запровадження ліцензування у сфері захисту персональних даних, розробки стандартів збирання та обробки персональних даних, сертифікування інформаційних систем з їх обробки тощо;

- створенні реєстрів баз персональних даних та основних суб'єктів ринку персональних даних громадян; 
ГАЛУЗЕВИЙ АСПЕКТ РОЗВИТКУ НАЦІОНАЛЬНОГО ГОСПОДАРСТВА

- формуванні незалежного регулятора, цілепокладанням якого є здійснення державної політики у сфері нагляду за дотриманням вимог у сфері захисту персональних даних громадян;

- формування ринкових засад функціонування інформаційної галузі з пріоритезацією безпекової складової, де кінцевий споживач розглядатиметься як поінформований щодо напрямів та обсягів подальшої обробки його персональних даних, активний та повноправний учасник на ринку персональних даних.

\section{Список використаних джерел}

1. 4 мільйони українців працюють за кордоном - дослідження Центру економічної стратегії. URL: http://uacrisis.org/ua/66428-research-on-labor-migration-ces.

2. Дубина М., Козлянченко О. Концептуальні аспекти дослідження сутності діджиталізації та іiі ролі у розвитку сучасного суспільства. Проблеми і перспективи еконоліки та управління. 2019. № 3 (19). C. 21-32. URL: https://ppeu.stu.cn.ua/tmppdf/604.pdf.

3. Звіт про роботу Національної комісії, що здійснює державне регулювання у сфері зв'язку та інформатизації за 2018 рік. Київ, 2019. 72 c. URL: https://nkrzi.gov.ua/images/upload/142/ 8484/Zvit za 201829032019 new.pdf.

4. Звіт про роботу НКРЗІ за 2016 рік. Київ 2017. $102 \mathrm{c}$. URL:https://nkrzi.gov.ua/ images/upload/142/6852/Zvit_NCCIR_2016.pdf.

5. Кравцова М. О. Сучасний стан і напрями протидії кіберзлочинності в Україні. Вісник кримінологічної асоиіації Украӥни. 2018. № 2 (19). C. 155-166. URL:http://dspace.univd.edu.ua/ xmlui/bitstream/handle/123456789/3848/Suchasnyi\%20stan\%20i\%20napriamy\%20protydii\%20kiberz lochynnosti\%20v\%20Ukraini\%20_Kravtsova_2018.pdf?sequence=1\&isAllowed=y.

6. Оліфіренко Л., Письменюк М. Критерії ефективності інтернет-технологій в аспекті планування маркетингових комунікацій. Проблеми і перспективи економіки та управління. 2019. № 3 (19). C. 33-44. URL: https://ppeu.stu.cn.ua/tmppdf/605.pdf.

7. Павлюк О. Будь-хто міг отримати дані про понад 6 млн виборців Ізраїлю - через недолік у мобільному додатку партії прем'єра. URL: https://hromadske.ua/posts/zlamali-mobilnij-dodatokpartiyi-premyera-izrayilyu-tam-osobista-informaciya-ponad-6-mln-viborciv.

8. Проникнення Інтернету в Україні. 22 c. URL: https://inau.ua/sites/default/files/file/1910/ dani_ustanovchyh_doslidzhen_iii_kvartal_2019_roku.pdf.

9. Україна - друга в Європі за темпами зростання ринку електронної комерції. URL: https://espreso.tv/news/2018/12/05/-

ukrayina_druga_v_yevropi_za_tempamy_zrostannya_rynku_elektronnoyi_komerciyi.

10. Elvy, Stacy-Ann. Paying for privacy and the Personal Data economy. Columbia Law Review. Vol. 117, No. 6 URL: https://columbialawreview.org/content/paying-for-privacy-and-the-personaldata-economy.

11. Internet World Stats. URL: internetworldstats.com.

12. Types of Personal Data. 34 p. URL: https://www.google.com/search? $\mathrm{q}=$ the+personal + data + market\&rlz=1C1GGRV_enUA751UA751\&tbm=isch\&source=iu\&ictx $=1 \&$ fir $=4$ yoXIWUBQYCQM $\% 253 \mathrm{~A} \% 252 \mathrm{Clj}-\mathrm{dv}-\mathrm{OWGBRFAM} \% 252 \mathrm{C}$ \&vet=1\&usg=AI4 -kTzS0zPtash08y8nk4vhQT9JobNg\&sa=X\&ved=2ahUKEwjQtrX69KPoAhUḦxqYKHftcCYEQ9QEwDnoECAgQIA \#imgrc $=-4$ yoXIWUBQYCQM.

13. Worthington I. \& Worthington S. Are Personal Data Stores about to become the NEXT BIG THING? URL: https://medium.com/@shevski/are-personal-data-stores-about-to-become-the-next-bigthing-b767295ed842.

14. Zezulková M. Rise of the Personal Data Economy. URL: https://vetri.global/rise-of-thepersonal-data-economy.

\section{References}

1. 4 miliony ukraintsiv pratsiuiut za kordonom - doslidzhennia Tsentru ekonomichnoi stratehii [4 million Ukrainians work abroad - a study by the Center for Economic Strategy]. Retrieved from http://uacrisis.org/ua/66428-research-on-labor-migration-ces.

2. Dubyna, M., Kozlianchenko, O. (2019). Kontseptualni aspekty doslidzhennia sutnosti didzhytalizatsii ta yii roli u rozvytku suchasnoho suspilstva [Conceptual aspects of research of the nature of dizhitalization and its role in the modern society development]. Problemy i perspektyvy 
ГАЛУЗЕВИЙ АСПЕКТ РОЗВИТКУ НАЦІОНАЛЬНОГО ГОСПОДАРСТВА

ekonomiky ta upravlinnia - Problems and prospects of economic and management, 3 (19), 21-32. Retrieved from https://ppeu.stu.cn.ua/tmppdf/604.pdf.

3. National Commission for the State Regulation Of Communications And Informatization (2019). Zvit pro robotu Natsionalnoi komisii, shcho zdiisniuie derzhavne rehuliuvannia u sferi zviazku ta informatyzatsii za 2018 rik [Report on the work of the National Commission for State Regulation in the Field of Communication and Informatization for 2018]. Kyiv. Retrieved from https://nkrzi.gov.ua/images/upload/142/8484/Zvit_za_2018_29032019_new.pdf.

4. National Commission for the State Regulation Of Communications And Informatization (2017). Zvit pro robotu NKRZI za 2016 rik [Report on the work of the HKP3I for 2016]. Kyiv. Retrieved from https://nkrzi.gov.ua/images/upload/142/6852/Zvit NCCIR 2016.pdf.

5. Kravtsova, M. O. (2018). Suchasnyi stan i napriamy protydii kiberzlochynnosti v Ukraini [The current state and trends of combating cybercrime in Ukraine]. Visnyk Kryminolohichnoi Asotsiatsii Ukrainy - Bulletin of the Criminological Association of Ukraine], 2(19), 155-166. Retrieved from http://dspace.univd.edu.ua/xmlui/bitstream/handle/123456789/3848/Suchasnyi\%20stan\%20i\%20napriamy \%20protydii\%20kiberzlochynnosti\%20v\%20Ukraini\%20 Kravtsova 2018.pdf?sequence=1\&isAllowed=y.

6. Olifirenko, L., Pysmeniuk, M. (2019). Kryterii efektyvnosti internet-tekhnolohii v aspekti planuvannia marketynhovykh komunikatsii. [Conceptual aspects of research of the nature of dizhitalization and its role in the modern society development]. Problemy i perspektyvy ekonomiky ta upravlinnia - Problems and prospects of economic and management, 3 (19), 33-44. Retrieved from https://ppeu.stu.cn.ua/tmppdf/605.pdf.

7. Pavliuk O. (n.d.). Bud-khto mih otrymaty dani pro ponad $6 \mathrm{mln}$ vybortsiv Izrailiu - cherez nedolik u mobilnomu dodatku partii premiera. [Anyone could get data on over 6 million Israeli voters - due to a shortcoming in the Prime Minister's mobile application]. Retrieved from https:/hromadske.ua/posts/zlamali-mobilnij-dodatok-partiyi-premyera-izrayilyu-tam-osobista-

informaciya-ponad-6-mln-viborciv.

8. Pronyknennia Internetu $v$ Ukraini [Internet penetration in Ukraine]. Retrieved from https://inau.ua/sites/default/files/file/1910/dani ustanovchyh doslidzhen iii kvartal 2019 roku.pdf.

9. Ukraina - druha $v$ Yevropi za tempamy zrostannia rynku elektronnoi komertsii [Ukraine is the second largest European e-commerce market in Europe]. Retrieved from https://espreso.tv/news/ 2018/12/05/-ukrayina_druga_v_yevropi_za_tempamy_zrostannya_rynku_elektronnoyi_komerciyi.

10. Elvy, Stacy-Ānn. Paying for privacy and the Personal Data economy. Columbia Law Review, 117 (6). Retrieved from https://columbialawreview.org/content/paying-for-privacy-and-the-personaldata-economy.

11. Internet World Stats. (2020). Retrieved from internetworldstats.com.

12. Types of Personal Data. (2015). Retrieved from https://www.google.com/search?q=the+ personal+data + market\&rlz $=1$ C1GGRV_enUA751UA751\&tbm $=$ isch\&source $=$ iu\&ictx $=1 \&$ fir $=4$ yoXl WUBQYCQM\%253A\%252CIj-dv-OWGBRFAM\%252C_\&vet=1\&usg=AI4_-kTzS0zPtash08y8nk4vhQT9JobNg\&sa=X\&ved=2ahUKEwjQtrX69KPoĀhUHxqYKHftcCYEQ9QEwDnoECAgQIA \#imgrc $=-4$ yoXlWUBQYCQM).

13. Worthington, I. \& Worthington, S. (2018). Are Personal Data Stores about to become the NEXT BIG THING? Retrieved from https://medium.com/@shevski/are-personal-data-stores-about-tobecome-the-next-big-thing-b767295ed842.

14. Zezulková, M. (2018). Rise of the Personal Data Economy. Retrieved from https://vetri.global/rise-of-the-personal-data-economy.

|Шандрівська Олена Свгенівна - кандидат економічних наук, доцент, доцент кафедри маркетингу і логіс-

тики, Національний університет «Львівська політехніка» (вул. С. Бандери, 12, м. Львів, 79000, Україна).

Шандривска Елена Евгеньевна - кандидат экономических наук, доцент, доцент кафедры маркетинга и логистики, Национальный университет «Львовская политехника» (ул. С. Бандеры, 12, г. Львов, 79000, Украина).

Shandrivska Olena - PhD in Economics, Associate Professor, Associate Professor of Department of Marketing and

Logistics Lviv Polytechnic National University (12 Bandera Str., 79000, Lviv, Ukraine).

E-mail: olena.y.shandrivska@lpnu.ua

ORCID: https: // orcid.org/0000-0002-4335-2423

ResearcherID: V-1390-2017

Scopus Author ID: https://www.scopus.com/authid/detail.uri?authorId=57190255515

Шандрівська О. Засади формування ринку персональних даних громадян: безпековий зріз. Проблеми і перспективи економіки та управління. 2019. № 4 (20). С. 246-254. 